\title{
Social Trust and Types of Classroom Activities: Predictors of Language Learning Motivation
}

\author{
Hossein Khodabakhshzadeh \\ English Department, Torbat-e Heydarieh Branch, Islamic Azad University, Torbat-e Heydarieh, Iran \\ E-mail: Kh.phdtbt2015@gmail.com \\ Zahra Kafi (Corresponding author) \\ English Department, Torbat-e Heydarieh Branch, Islamic Azad University, Torbat-e Heydarieh, Iran \\ E-mail: zahra.kafi.p@gmail.com \\ Hanieh Garmabi \\ English Department, Torbat-e Heydarieh Branch, Islamic Azad University, Torbat-e Heydarieh, Iran \\ E-mail: Hanieh_garmabi@yahoo.com
}

$\begin{array}{lll}\text { Received: 21-09-2016 } & \text { Accepted: 28-12-2016 } & \text { Advance Access Published: January } 2017 \\ \text { Published: 01-03-2017 } & \text { doi:10.7575/aiac.ijalel.v.6n.2p.147 } & \text { URL: http://dx.doi.org/10.7575/aiac.ijalel.v.6n.2p.147 }\end{array}$

\begin{abstract}
The present study examined the role of social trust and types of classroom activities as some probable significant predictors of language learning motivation on a sample of 200 Iranian EFL upper-intermediate learners who have been selected randomly. Consequently, the participants completed three questionnaires, Language Learning Motivation Inventory, Classroom and school Community Inventory, and Classroom Activities Inventory, the reliability and validity of each have been checked previously. After running Multiple Regression through SPSS Software, the results revealed that social trust and types of classroom activities accounted for $16.7 \%$ of the variance in language learning motivation. Although each of them had a unique impact on language learning motivation, "Deep Language Use" as one of the types of classroom activities had a greater contribution to English as a foreign language learning motivation $(002<.05)$, outweighing social trust as a more important predictor, $(.005<.05)$. Finally, pedagogical implications along with suggestions for further studies are discussed.
\end{abstract}

Keywords: Types of classroom activities, Social trust, Language learning motivation, EFL learners

\section{Introduction}

Motivation has been the focus of many researchers and studies during the past centuries and the crucial role it has regarding learners' achievement and language learning. Therefore, considering classrooms as smaller communities within which many issues may affect learners' motivation towards learning a language has made the researchers interested in pinpointing some factors that may be influential. Among the effective factors the present study has highlighted the role of social trust along with types of classroom activities as some probable predicators of language learning motivation.

Following the same perspective, some researchers in the field have looked upon schools and classrooms consisting of a set of complicated social circumstances where students come to share their fears, worries, success, values, and norms among each other (Hofman, Hofman, \& Guldemond, 2001; Rovai, Wighting, \& Lucking, 2004). Besides, Hofman et al., (2001) have stated that students' affective and cognitive functioning are shaped as a matter of their school and schooling, the point which was mentioned in Rovai, Wighting, \& Lucking (2004). On the other hand, studies done related to effectiveness of schools and their classrooms have claimed the idea that students' behavior and achievement are hugely affected by the school, classroom environments, and the activities that take place in them (Rutter \& Maughan, 2002; Rovai, Wighting, \& Lucking, 2004).

To this end, the present study aimed at examining social trust and types of classroom activities implemented in the educational settings to see whether they can be considered as some of the probable predictors of language learning motivation.

\section{Review of Literature}

\subsection{Foreign Language Learning Motivation}

Motivation has been viewed as one of the most important elements in language learning, a factor which can be quite dependent or independent from the classroom setting or what so ever that can be related to it. Moreover, motivation has been looked upon from various aspects, therefore having various kinds. But among all, motivation about the language 
has got huge impacts on learning outcomes (Bernard, 2010). Also, throughout the previous studies, it has been proved that motivation plays a crucial role in language learning, completely separated from language aptitude (Gardner, 1972; Wigfield \& Wentzel, 2007). So, language motivation can be manipulated in order to increase learning outcomes on part of learners as well as fostering a positive motivation in classroom settings and among learners (Bernard, 2010). Consequently, motivation can affect other aspects of human as well, such as identity development (McCaslin, 2009; Roeser \& Peck, 2009). Besides, motivation can be influenced by factors such as cultural issues, language attitudes, and geopolitical considerations, possessing a sociocultural nature (Bernard, 2010).

On the other hand, motivation has been looked upon as a social factor (Walker, 2010), that is motivation is something which is situated and differs from one context to the other. Accordingly, lots of new studies have been done focusing on sociocultural aspects of motivation which is examined through peer learning, internalization, or intersubjectivity (Sivan, 1986, as cited in Walker, 2010). Besides, a lot of studies have pinpointed intrinsic motivation as a factor which extremely affects students' performance. As a matter of fact, learners who possess intrinsic motivation along with receiving autonomy-support from their instructors, consider themselves to be more competent and have a greater interest in learning the language (Bernard, 2010). Also, Vallerand, Fortier \& Guay (1997) in their studies have reached to the point that the quality of motivation is deeply linked to students' retention. Therefore, as stated elsewhere in the article, having a great deal of motivation leads to better and higher grades and achievements (Grolnick \& Ryan, 1987). Generally talking, motivation towards language and language learning is quite context based which affects lots of other dimensions of a simple so called classroom and learner such as friendship, knowledge (Dornyei, 1994)and the like that if paid attention to and triggered appropriately will lead to a successful education and a lot more achievements.

\subsection{Classroom Activities and Foreign Language Learning Motivation}

Considering language learning and continuing education, classroom activities do play a crucial role in making students motivated and involved in the target subject matter. For doing so, the instructor should follow and choose particular activities that best suit the goal, context, and learners' needs such as intrinsic, extrinsic and the like (Bernard, 2010). In the same research it has been proved that the instructors who try to understand students and let them choose or say their opinions about what sorts of activities to do within class time are more interested in learning the language and more successful (Bernard,2010). In addition, Miserandino (1996) in the conducted study has mentioned that students who are more competent and intrinsically motivated are more curious about the types of activities which are going to be done in the classroom, receiving better grades. On the other hand, results of similar studies revealed that students' performance as well as grades during a course decreased when the activities came to be controlled ones, reaching to negative learning outcomes (Grolnick \& Ryan, 1987). Also, Renninger (2009) has stated that interest and motivation on part of learners can be developed over time based on the issues such as activities, texts and the like. Besides, activities which contain multiple goals have found to be highly motivating (Ford, 1992, As cited in Bernard, 2010).

Moreover, not even the type of classroom activities but also the discourse which exists between instructors and learners do impact the learning outcome. Regarding the aforementioned issue, Kiemer, et al. (2015) have conducted an experimental study, the result of which has revealed that employing a video-based teacher professional development played a great role in improving teacher and learners' interaction, interest, and learning. In addition, choosing a wrong type of classroom activity can affect learners' attitudes towards learning a language (Lee, Schallert, \& Kim, 2015). Besides, Brophy (2008) has mentioned the fact that students are more willing to take part in activities which have values, considering the activity itself or the outcomes it may have. So, it would be much better to set the curricula around general ideas which are meaningful and later on apply activities in the classroom that are authentic and can be applied in real life situations. That is when students are involved in activities which are related to their present life, they find them quite reasonable to take part in willingly (Brophy, 2008, as cited in Bernard, 2010).

\subsection{Social trust and Foreign Language Learning Motivation}

The best learning takes place when learners are motivated and involved in classroom activities and the school context. That is learning which involves both the academic and social aspects of a school and its classes (Astin, 1984, as cited in Rovai, Wighting, \& Lucking, 2004). Besides, such a commitment needs a great deal of energy spent on relations and activities done within the students' school or better to say their classrooms (Astin, 1984). Consequently, such a kind of learning, from a social and cognitive view, happens when there is a positive social environment, rapport, and motivation among the members of that small community of learning. Moreover, some researchers do believe that trust is an issue which is situated or better to say considering trust as a complicated factor which varies from one context to the other (Evans \& Revelle, 2008). Also, it has been proved previously that individual differences do affect social trust to minor extents (Glaeser, Laibson, Scheinkman, \& Soutter, 2000; Snijders \& Keren, 2001, as cited in Evans \& Revelle, 2008). On the other hand, social trust by itself consists of some subcategories such as reciprocity and betrayal and the like that each of which can be studied separately (Evans \& Revelle, 2008).

Regarding school climate and the social trust which exist among learners, Bolender (1997) has asserted that having an orderly, safe environment at schools highly impacts learning outcomes and students' achievements (As cited in Bennett,2001). In addition, Getzels and Thelen's (1960) model, within their study, has proved the fact that "personality needs, role expectations, and classroom climates interacted and predicted group behaviors, including learning". Climate or that social trust develops as a result of the teacher's transactional style or the way in which role requirements and personality needs are balanced in a classroom (Deng, 1992). As a matter of fact, considering classroom as a smaller community which consists of a social system highly correlates with other bigger social systems such as school and later on the community within which they are living in (Bennett, 2001), highlighting the fact of how much that climate or 
better to say the social trust among the members of a classroom affects the upcoming outcomes within a larger community, which can be formed so early on. Therefore, school climate/social trust is a combination of psychological and nonpsychological aspects (Deal, 1993, as cited in Rovai, Wighting, \& Lucking, 2004). To put it in a nutshell, social trust or that classroom climate associates the goal behavior of a smaller circle to a bigger one, greatly impacting each other as well as the learning outcome.

Based on the aforementioned related researches and studies, to the best of understanding, so few studies have been conducted to investigate social trust and types of classroom activities along with language learning motivation to realize whether they are interrelated or not. Therefore, the researchers' focus is on social trust and types of classroom activities to find out whether they can be some of the probable predicators of language learning motivation or not. The analysis of results will have so many efficient implications for teacher educators, teachers as well as learners. Therefore, in the present study we sought out answers to the following questions:

- Can social trust be considered as a significant predictor of Iranian EFL learners' language learning motivation?

- Can types of classroom activities be considered as significant predictors of Iranian EFL learners' language learning motivation?

\section{Methodology}

\subsection{Participants}

The participants of the study were selected randomly from Zabansara Language School, Mashhad, and Kish Language School, Tehran, Iran. Consequently, 200 male and female Iranian EFL upper-intermediate students took part in the study. Besides, their age ranged between 15 and 20 and their native language was Farsi.

\subsection{Instrumentation}

\subsubsection{Language Learning Motivation Inventory}

The Language Learning Motivation Inventory is a researcher made questionnaire by Kafi and Motallebzadeh (2015), the aim of which is to find learners' motivation towards learning a second/foreign language. The aforementioned questionnaire consists of 23 items which are in a form of five-point Likert scale ranging from "strongly agree" to "strongly disagree". In addition, the questionnaire has been expert validated within the same study and it possesses a reliability of 0.8 . Moreover, a Cronbach's $\alpha$ of .729 was gained for the present study after piloting the questionnaire.

\subsubsection{Classroom and School Community Inventory}

The second instrument applied in the study was Classroom and School Community Inventory. Rovaia, Wightinga, and Lucking (2004) have done a study trying to develop and validate their CSCI using the Rovai's CCS (2002) which consists of 20 self-report items examining community within the classroom settings. So, the items are in a form of fivepoint Likert scale ranging from "strongly agree" to" strongly disagree" . In addition, the instrument has got a high content validity as well as a reliability of 0.93 . To this end, the researcher made the needed modifications on the aforementioned questionnaire for it to meet the needs of the present study which aims at estimating the social trust that may exist in classroom settings among students. Better to say, those items which highly correlate with measuring social trust in classroom environments were elicited out of the aforementioned questionnaire and were applied in the present study. After piloting the questionnaire for the present study a Cronbach's $\alpha$ of .807 was obtained.

\subsubsection{Classroom Activities Inventory}

Also, Classroom Activities Inventory was considered to be the third instrument for the present study. Students through the CAI were asked to check their answers about how far they agree with having a set of nineteen specific classroom activities either in the classroom or as homework to see which type of activities are more related to making students motivated in a classroom context. The questionnaire is in a form of five-point frequency scale ranging from "Daily" to "Never" (Bernard, 2010) but the researchers have modified the choices to "strongly agree" to "strongly disagree" to fit into the needs of the study. Besides, the validity and reliability of the questionnaire have been checked previously within the same study. Moreover, regarding the present research a reliability of .792 was obtained after piloting the survey.

\subsection{Procedure}

In order to conduct the present study first of all the researchers have done the modifications needed regarding the CSCI and CAI to meet exactly the needs and aims of the present research. By the time the modifications were done the inventories were piloted for checking the reliability of the modified questionnaires. After that, the three questionnaires, CSCI, CAI, and LLMI were handed to the participants of the study that have been chosen previously by the researchers in a random way to check their answers within 20 minutes. And at the end, the results of the study were analyzed by running Multiple Regression.

\section{Results}

In order to find the answer to the research question i.e. whether social trust and types of classroom activities can be considered as some of the probable predictors of language learning motivation, Multiple Regression was employed the results of which are illustrated in the following tables. 


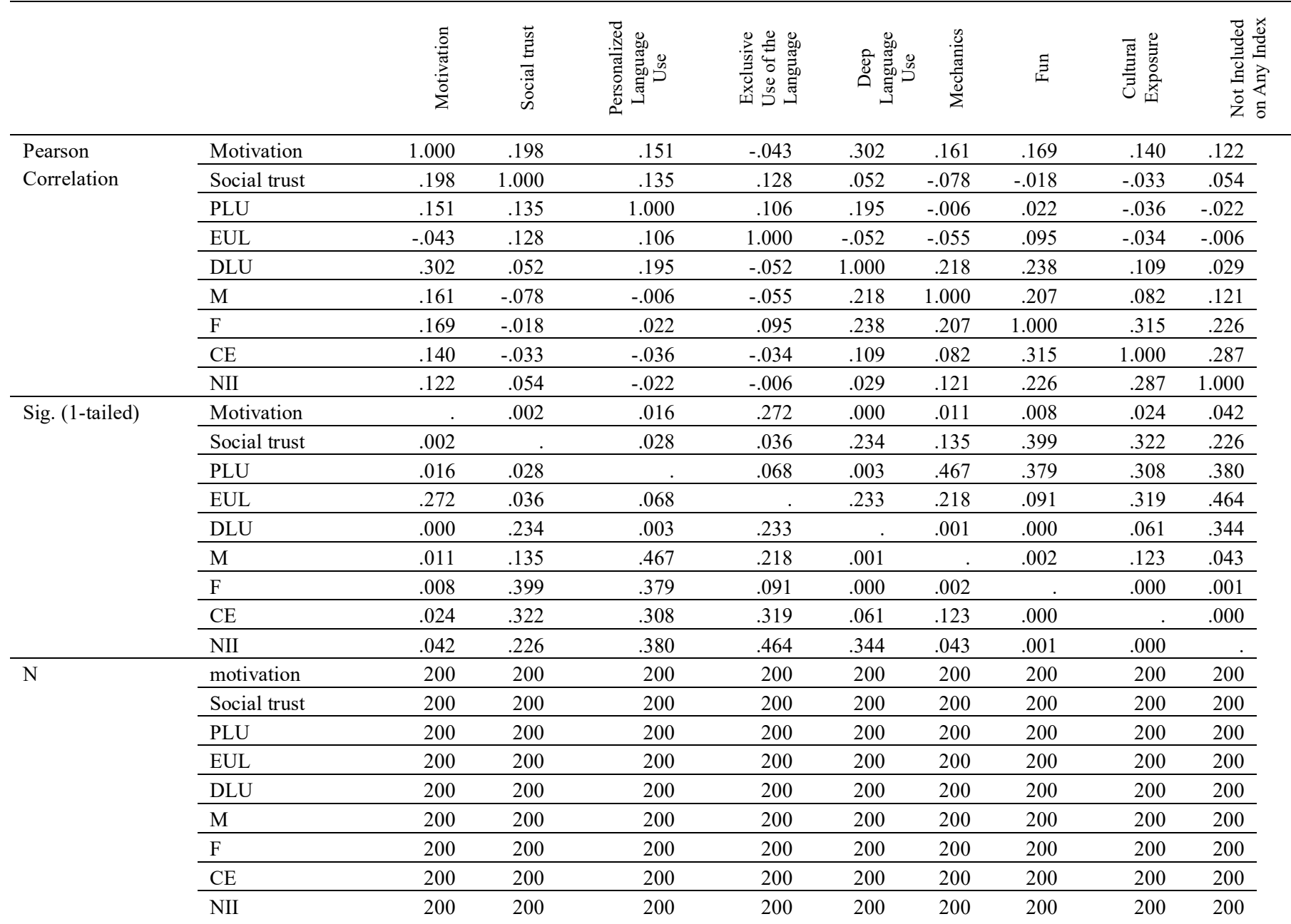

As depicted in Table 1, all the predictors possess a considerable amount of relation with language learning motivation among which "Deep Language Use", one type of classroom activity, has got the most preferable relation with the dependent variable, language learning motivation, .302>.3. After all, to find out which one (s) of these relations is statistically significant, the Sig. goes for all the predictors except for the "Exclusive use of the Language" (.272>.05). Besides, it's worth mentioning that "Deep Language Use" as one of the types of classroom activities has the highest Sig. value $(.000<.05)$.

Moreover, to check the multicollinearity assumption and also for comparing the contribution of each of the independent variables to the dependent variable, Coefficient Correlation is employed and the results are shown in Table 2.

Table 2. Coefficients of Correlation

\begin{tabular}{|c|c|c|c|c|c|c|c|c|c|c|c|c|c|}
\hline \multicolumn{2}{|c|}{ Model } & \multicolumn{2}{|c|}{$\begin{array}{c}\text { Unstandardized } \\
\text { Coefficients }\end{array}$} & \multirow{2}{*}{$\begin{array}{l}\text { Standa } \\
\text { rdized } \\
\text { Coeffi } \\
\text { cients } \\
\text { Beta }\end{array}$} & \multirow[t]{2}{*}{$\mathrm{t}$} & \multirow[t]{2}{*}{ Sig. } & \multicolumn{2}{|c|}{$\begin{array}{c}95 \% \text { Confidence } \\
\text { Interval for B }\end{array}$} & \multicolumn{3}{|c|}{ Correlations } & \multicolumn{2}{|c|}{ Collinearity Statistics } \\
\hline & & B & $\begin{array}{l}\text { Std. } \\
\text { Error }\end{array}$ & & & & $\begin{array}{l}\text { Lower } \\
\text { Bound }\end{array}$ & $\begin{array}{l}\text { Upper } \\
\text { Bound }\end{array}$ & $\begin{array}{l}\text { Zero- } \\
\text { order }\end{array}$ & Partial & Part & Tolerance & VIF \\
\hline \multirow[t]{9}{*}{1} & $\begin{array}{l}\text { Const } \\
\text { ant) }\end{array}$ & $\begin{array}{r}39.54 \\
3 \\
\end{array}$ & 7.394 & & 5.348 & .000 & 24.960 & 54.126 & & & & & \\
\hline & $\begin{array}{l}\text { Socia } \\
1 \text { trust }\end{array}$ & .302 & .107 & .191 & 2.818 & .005 & .091 & .514 & .198 & .200 & .186 & .954 & 1.049 \\
\hline & PLU & .507 & .378 & .092 & 1.342 & .181 & -.238 & 1.252 & .151 & .097 & .089 & .932 & 1.073 \\
\hline & EUL & -.282 & .302 & -.063 & -.935 & .351 & -.878 & .313 & -.043 & -.068 & -.062 & .950 & 1.052 \\
\hline & DLU & .730 & .231 & .224 & 3.157 & .002 & .274 & 1.186 & .302 & .223 & .208 & .864 & 1.158 \\
\hline & $\mathrm{M}$ & .420 & .300 & .097 & 1.403 & .162 & -.171 & 1.011 & .161 & .101 & .093 & .909 & 1.100 \\
\hline & $\mathrm{F}$ & .227 & .257 & .065 & .884 & .378 & -.279 & .733 & .169 & .064 & .058 & .807 & 1.240 \\
\hline & $\mathrm{CE}$ & .303 & .281 & .077 & 1.078 & .282 & -.251 & .856 & .140 & .078 & .071 & .844 & 1.184 \\
\hline & NII & .204 & .245 & .059 & .833 & .406 & -.280 & .688 & .122 & .060 & .055 & .884 & 1.131 \\
\hline
\end{tabular}


As it is depicted in Table 2, The Tolerance values for each of the independent variables as predictors of language learning motivation are not less than .10; consequently the assumption of multicollinearity isn't violated $(.954, .932, .950, .864, .909, .807, .844$, and .884$)$. In addition, having VIF values well below 10 can be considered as another support for not violating the multicollinearity $(1.049,1.073,1.052,1.158,1.100,1.240,1.184$, and 1.131).

On the other hand, Standardized Coefficients (Beta) was utilized to compare the degree of the contribution of each independent variable to the prediction of the dependent variable. Therefore, the larger the Beta value, the more contribution that particular independent variable has over the dependent variable. The largest Beta value goes for "Deep language Use "and the least Beta value is possessed by "Not Included on any Index", types of classroom activities. Also, "Social trust" with a Beta value of .191 has proved to be the second independent variable which has got a considerable amount of contribution to the language learning motivation, the dependent variable.

Finally, the Sig. values were employed to realize whether the Beta values are making a statistically significant contribution/prediction to the dependent value or not. Among all, "Deep Language Use and "Social trust" have a significant contribution to language learning motivation respectively $(.002 \& .005<.05)$. As a result, the other independent variables in the present study don't have any significant contribution/ prediction regarding language learning motivation.

Table 3 shows how much of the language learning motivation is predicted according to the independent variables, social trust as well as types of classroom activities.

Table 3. Model Summary

\begin{tabular}{lllll}
\hline Model & $\mathrm{R}$ & R Square & Adjusted R Square & $\begin{array}{l}\text { Std. Error of the } \\
\text { Estimate }\end{array}$ \\
\hline 1 & $.408^{\mathrm{a}}$ & .167 & .132 & 8.64021 \\
\hline
\end{tabular}

The results in Table 3 show that social trust and types of classroom activities accounted for $16.7 \%$ of the variance in language learning motivation.

\section{Discussion and Conclusion}

The present study aimed at investigating social trust, in classroom settings, and types of classroom activities as some probable significant predictors of second/foreign language learning motivation.

Although so few studies have tapped these two variables together as predictors of language learning motivation, some have done researches on each variable separately. Regarding types of classroom activities and language learning motivation in a study done by Bernard (2010), "Personalized Language use" has been chosen as the type of classroom activity which has got the greatest contribution to language learning motivation. As these sorts of classroom activities set aside a considerable amount of autonomy on part of learners to be involved in activities and tasks which let them think/write about what matters the most to them considering real life situations and experiences. Besides, instructors who allow the use of such classroom activities bring about a degree of support on part of learners for showing respect for their learners' perspectives and ideas leading to a higher level of classroom and language learning motivation. Along with the same perspective and the same study "Fun" activities came to take the second place as one of the other predictors of language learning motivation as well as learner' learning outcome ( see Bernard, 2010 ). Findings of the present survey had a contradictory outcome regarding Iranian EFL classroom settings and learners' perspectives towards types of classroom activities. After analyzing the results through Multiple Regression it was revealed that "Deep Language Use" has the greatest contribution to EFL language learning motivation in the aforementioned context. Consequently, Iranian EFL learners do consider activities such as classroom discussions, role plays, doing projects, reading English literature, poetry, and stories, as well as creating dialogues more motivating for learning English as a foreign language.

Regarding social trust in classroom settings as one of the other variables/predictors of the present study and its role in language learning motivation several researches have been conducted. Among all, in a survey done by Rovaia, Wightinga, and Lucking (2004) the results have illustrated that having a sense of community or better to say a positive social trust leads to a lifelong, satisfactory, productive "educational journey" on part of learners, the point which isn't present in distance education. In line with the results of the aforementioned study, within the current research, social trust that exists in a classroom setting has got the second role in making Iranian EFL students more motivated towards learning English, a minor predictor.

There are some pedagogical implications for EFL teachers and learners as well. According to the findings of the study, teachers who have got a crucial role in students' learning and education would better implement classroom activities that make students more motivated in learning English as a foreign language in a continuous way. For doing so, as the results have pinpointed, teachers can apply some activities such as role plays, creating dialogues, having some readings over English literature and stories and the like to make language learning motivation higher and better. Moreover, learners can extend their language abilities/skills by attending in the activities they like as classroom or homework tasks. For all these to take place, teachers should create a friendly classroom environment within which social trust exists in a reciprocal way, among teacher and learners. So they can freely express their ideas about the materials that are going to 
be covered in a course of study as well as the type of classroom tasks and activities, being able to seek help and guidance on part of each other.

After all, although the present study had some unique contributions/results regarding the context and variables under study, the results should be interpreted in light of some limitations. First of all, Classroom Activity Inventory was based on some limited types of classroom activities, these may be more based on the context and aims of the studies. Also, social trust was examined just based on classroom settings and not on school climate/social trust. Besides, the data was collected just from two cities in Iran and among upper intermediate Iranian EFL learners. As a result, all these limitations can be considered as some suggestions for further studies.

\section{References}

Astin, A. W. (1984). Student involvement: A developmental theory for higher education. Journal of College Student Personnel,25, 297-308.

Bennett, J. (2001). The relationship between classroom climate and student achievement. Doctoral Dissertation, University of North Texas.

Bernard, J. (2010). "Motivation in foreign language learning: The relationship between classroom activities,motivation, and outcomes in a university language learning environment". Dietrich College of Humanities and Social Sciences. Camegie Mellon University.

Bolender, M. (1997). A Study of The Evolving Image of A New School Within the Context of School Effectiveness. SSTA Research Centre.

Brophy, J. (2008). Developing students' appreciation for what is taught in school. Educational Psychologist, 43(3), 132141.

Deal, T. E. (1993). The culture of schools. In M. Sashkin, \& H. J. Walberg (Eds.), Educational leadership and School Culture,3-18. Berkeley, CA7 McCutchan Publications.

Deng, B. (1992). A multilevel analysis of classroom climate effects on mathematics achievement of fourth-grade students (Clearinghouse No. SE052843). Memphis, TN: Memphis State University. ERIC Document Reproduction Service No. Ed 348222

Dornyei, Z. (1994). Motivation and motivation in the foreign language classroom. The Modern Language Journal, 78,273-84.

Evans, A. M., \& Revelle, W. (2008). Survey and behavioral measurements of interpersonal trust. Journal of Research in Personality, 42,1585-1593.

Ford, M. E. (1992). Motivating Humans: Goals, Emotions, and Personal Agency Beliefs. Newbury Park, CA: SAGE Publications, Inc.

Gardner, R. C. (1972). Attitudes and motivation in second language learning. In Reynolds, Allan G. (Ed.), Bilingualism, Mulitculturalism, and Second Language Learning, 43-64. Hillsdale, NJ: Lawrence Erlbaum Associates, Inc.

Getzels, J., \& Thelen, H. (1960). The classroom as a unique social system. National Society for the Study of Education Yearbook, 59, 53-81.

Glaeser, E. L., Laibson, D. I., Scheinkman, J. A., \& Soutter, C. L. (2000). Measuring trust. Quarterly Journal of Economics, 115(3), 811-846.

Grolnick, W. S. and Ryan, R. M. (1987). Parent styles associated with children's self- regulation and competence in school. Journal of Educational Psychology, 81(2), 143-154.

Hofman, R. H., Hofman, W. H., \& Guldemond, H. (2001). Social context effects on pupils'perceptions of school. Learning and Instruction, 11(3), 171-194.

Kafi, Z., \& Motallebzadeh, K. (2015). Effective teaching and language learning motivation: A study on the interconnection. Indonesian EFL Journal, 1 (2), 135-143.

Kiemer,k., Groschner, A., \& Seidel, T. et al. (2015). Effects of a classroom discourse intervention on teachers' practice and students' motivation to learn mathematics and science. Learning and Instruction, 35, 94-103.

Lee,J., Schallert, D.L., \& Kim, E. (2015). Effects of extensive reading and translation activities on grammar knowledge and attitudes for EFL adolescents. Learning and Instruction, 52,38-50.

McCaslin, M. (2009). Co-regulation of student motivation and emergent identity. Educational Psychologist, 44(2), 137146.

Miserandino, M. (1996). Children who do well in school: Individual differences in perceived competence and autonomy in above-average children. Journal of Educational Psychology, 88(2), 203- 214.

Renninger, K. A. (2009). Interest and identity development in instruction: An inductive model. Educational Psychologist,44(2),105-118.

Roeser, R. W., \& Peck, S. C. (2009). An education in awareness: Self, motivation, and self-regulated learning in contemplative perspective. Educational Psychologist, 44(2), 119-136. 
Rovai, A. P. (2002). Development of an instrument to measure classroom community. Internet and Higher Education, 5(3), 197-211.

Rovai, A., Wighting, M., \& Lucking, R. (2004). The classroom and school community inventory: Development, refinement, and validation of a self-report measure for educational research. Internet and Higher Education 7,263-280.

Rutter, M. \& Maughan, B. (2002). School effectiveness findings. Journal of School Psychology, 40, 451-475.

Sivan, E. (1986). Motivation in social constructivist theory. Educational Psychologist 21, 209-233.

Snijders, C., \& Keren, G. (2001). Do you trust? Whom do you trust?. Advances in Group Processes, 18, $129-160$.

Vallerand, R. J., Fortier, M. S., \& Guay, F. (1997). Self-determination and persistence in a real-life setting: Toward a motivational model of high school dropout. Journal of Personality and Social Psychology, 72(5), 1161-1176.

Walker, R. A. (2010). Sociocultural issues in motivation. Elsevier, 6,712-717.

Wigfield, A. and Wentzel, K. R. (2007). Introduction to motivation at school: Interventions that work. Educational Psychologist, 42(4), 191-196. 